\title{
The Finnish Pentecostal Movement: An Analysis of Internal Struggle as a Process of Habitual Division
}

\section{Teemu T. Mantsinen}

The Finnish Pentecostal Movement (Helluntaiherätys, or $\mathrm{HH}$ ) is a century-old religious movement with nearly 50,000 baptized members. The $\mathrm{HH}$ is the major Pentecostal group in Finland; other groups are substantially smaller. It is also the largest Christian body outside the two former national churches: the Finnish Evangelical-Lutheran Church (Suomen evankelis-luterilainen kirkko) and the Finnish Orthodox Church (Suomen ortodoksinen kirkko). Among the internal struggles the Pentecostal movement in Finland has encountered in the past, the present one is the most severe. Traditionally favoring the independence of local congregations, the movement risks being divided by a dispute, namely as to whether or not it should develop from a loose network into a registered denomination. Today, the $\mathrm{HH}$ faces pressure from two camps: On the one hand, there are people who want to transform the movement, including its organizational basis. On the other, there are those who defend the traditional culture.

Historically, the Finnish Freedom of Religion Act has allowed the $\mathrm{HH}$ to remain unregistered without conflicts with the state, unlike in some other neighboring countries, like Russia (e.g., Löfstedt 2009, 158-159).

T.T. Mantsinen $(\bowtie)$

University of Turku, Turku, Finland

(C) The Author(s) 2018

J. Moberg, J. Skjoldli (eds.), Charismatic Christianity in Finland,

Norway, and Sweden, Palgrave Studies in New Religions and Alternative

Spiritualities, https://doi.org/10.1007/978-3-319-69614-0_5 
Instead, Pentecostal congregations have used the Association Act, for nonprofit associations, to manage their resources (including property). While many Pentecostals consider the rights granted by the legislation to be sufficient, a growing number believe that remaining unregistered is not enough. It not only restricts them from obtaining the rights granted to other religious bodies, like the right to officiate marriages; many also believe that remaining unregistered gives an unfavorable impression of the movement. To the latter group, the question of registration is merely an organizational technicality, whereas for the former, registration poses a threat to the integrity of Pentecostal identity and to the assumed doctrinal purity. The division is most evident in the creation of two opposing organizational structures: the state-registered Pentecostal Church of Finland (Suomen helluntaikirkko, SHK) and an association of Pentecostal People (Helluntaikansa, HK). These groups coexist within, or on the borders of, the same movement $(\mathrm{HH})$, but have opposing views on issues like cultural practices, leadership, and organization, as well the movement's future. In this chapter, I address and analyze the current conflict and the factors behind the disruption from sociological perspectives. The main argument is that the organizational dispute is part of a deeper cultural division, resulting in different forms of social transformation within the movement. This process has brought about two different forms of Pentecostal habitus. In order to pinpoint and scrutinize these developments, I draw upon two different theoretical perspectives: Bourdieuan perspectives on identity, and transformational processes regarding religious movements.

\section{Movement Transformation}

From a sociological perspective, the question at the organizational level can be understood in terms of development from sect to denomination, or moderation of a revivalist movement and its consequences. In order to analyze the developments in the $\mathrm{HH}$, I draw upon the work of several sociologists who have discussed the matter. Max Weber saw "systematization of external conduct of life," "routinization of charisma," and "institutionalization of mundane systems" as natural developments in organizations that transformed in this way (Weber 1947, 358-373; 1956, 177-183). Weber also defines three types of authority involved: charismatic, traditional, and legal. The same categorization corresponds to styles of leadership: charismatic, patriarchal, and bureaucratic. With the idea of the routinization of charisma, Weber describes how a social group changes 
after the loss of a charismatic leader. In some cases, the search for a new charismatic leader is successful, whereas in other cases the group dissolves or undergoes institutionalization (1964, 328-386).

Thomas O'Dea describes the development from Charismatic-led movements to institutionalized communities in a slightly different way. $\mathrm{He}$ focuses on particular dilemmas that may emerge. Such dilemmas can be connected to motivation, inclusion/exclusion, or administration, as well as difficulties connected to how religious symbols and interpretations should be limited. This also includes issues of power and authority, and possible problems connected to different modes of conversion (O'Dea 1961). Richard H. Niebuhr took particular interest in the generational aspects of transformation, claiming that a sect may survive for one generation, after which it is prone to change (1957, 181-182). Similarly, Rodney Stark and William Sims Bainbridge have underlined differences between converted and socialized members, arguing that socialized generations of members are crucial to the transformation of a sect into a church. If the new generations obtain higher socioeconomic status, are religiously more moderate than their parents, and gain central positions in the hierarchy, the sect is likely to transform into a mainline church (Stark and Bainbridge 1985, 149-167). In the following, these theories are used as points of departure, but in order to nuance and conceptualize the transformations, I also employ the work of scholars more interested in cultural aspects.

\section{Pentecostal Identity as Habitus}

Religion is a multifaceted phenomenon that cannot be reduced to one particular dimension. It does not include only institutions, doctrines or rituals, but also lifestyles. According to Heinz Streib "religious styles are distinct modi of practical-interactive (ritual), psychodynamic (symbolic), and cognitive (narrative) reconstruction and appropriation of religion, that originate in relation to life history and life world," and are subjected to social change (Streib 2011, 149). The factors that shape such cultural preferences and expressions are of particular interest to the present analysis. Several scholars have noted how social class informs such expressions, and that class preferences may cut across whole movements. One example is Lawrence Mamiya's study of Black American Muslims, where he notes how differences between middle-class, moderate styles of expression and the more radical practices of the lower class divided the movement (1982). The relationships between class and preferences, or "taste," have been systematically 
elaborated on by Pierre Bourdieu (2010, see also Köhrsen 2008). Bourdieu portrays a habitus as a durable disposition, a system produced by structural conditions, and as a historical product $(1990,53-54)$. The habitus more or less determines how a person or group presents itself, its taste, behavior, and performance, in order to produce a coherent image and an acceptable disposition of experience. Finnish sociologist J.P. Roos strongly relates habitus with lifestyle; a habitus is a general approach to life, and a lifestyle is the enactment of that approach with living practices (1988, 30-33).

For Bourdieu, a habitus is not the result of subjective intention but of socialization. It is motivated by the intention to belong to something; in order to be included in a group, one has to learn and present a habitus compatible with the group (Bourdieu 1990, 62; 2000, 100; 2010, 166-167, 174). He furthermore makes a distinction between class habitus and individual habitus. While the individual habitus may be informed by multiple groups, a class habitus is shared by a socioeconomic segment of people (Bourdieu 1990, 60). Class cultures are cultivated in structural conditions, which means they are subject to change over time, and shaped by the participants' needs and resources, possibilities and identification (Bourdieu 2010, 373-393; see also Mantsinen 2014, 42-47). In my view, no group or class habitus fully determines a person's individual habitus, as individuals may draw upon different habituses in different situations. This may result from conscious decisions or underlying rationales dependent upon socializations. Relationships between individual agency and habitus can be illustrated by looking at how individuals mobilize different habituses in different contexts, in order to position themselves in webs of power present in various groups (cf. Bourdieu 1990, 53-56; Mahmood 2005, 26-27; Vanberg 1993, 189-191).

\section{Habitual Transformation}

Some scholars have criticized Bourdieu for disregarding the dynamic nature of habituses (Moberg 2013, 36). In any group, the habitus incorporates what aspects, practices, and styles can be included, performed, and tolerated in the cultural milieu. Knowledge of a group habitus enables members to employ this knowledge in the social network of roles and tastes. This empowers them to justify and rationalize practices influenced by their individual habituses and incorporate them into the group habitus (Mantsinen 2014, 152-155; cf. Bourdieu 1977, 87-89). If the expressions introduced are accepted, they may result in transformation of the entire group habitus. 
Such transformations may include changes in ritualized practices, even the appropriation of new goals and preferences, as Jessica Moberg has shown in her dissertation (Moberg 2013, 220). Rather than being passive victims of history, both groups and individuals are constantly engaged in negotiating and renegotiating elements of their habitus. Such processes are permeated with constant competition over the power to control and define practices, preferences, and styles included in the habitus, and thus its normative aspects. In this competition, certain classified and classifying tastes and lifestyles become dominant in the group's culture (Bourdieu 2010, 167).

Relating these theoretical perspectives to the field of Pentecostal studies, various attempts have been made to distinguish between different forms of Pentecostal-Charismatic habitus. One common approach has been to construct categories of Pentecostals according to their practices, for example the famous distinction between "Classic Pentecostals" and "Neo-Pentecostals" (Anderson 2014, 1-7). In this chapter, I do not apply this distinction, as I consider it more useful as an insider category than an analytical concept. The division of Pentecostalism into different "waves" is strongly influenced by theological understandings of history (see Barnett 1973; Hollenweger 1972). The concept of Neo-Pentecostalism is, in my view, also an Americentric and selective understanding of Pentecostal religiosity and its development (see Freston 1999; Hunt 2002, 1-2). Moreover, it does not correspond well with the history of the Finnish Pentecostal movement. This is despite the fact that some new Pentecostal groups that might be described as Neo-Pentecostal have adopted or developed new practices and rejected old Pentecostal traditions. Many of those that might be named Classical Pentecostal groups have done the samemaking the concept context-specific.

Instead, I prefer to discuss transformation in the $\mathrm{HH}$ by relating it to developments in Finnish society at large. Analyzing two habituses, traditionalist and postmodernist Pentecostalism, I apply concepts of traditionalism, modernism, and postmodernism that describe general ways of thinking and approaches to life and to the surrounding world. Zygmunt Bauman sees postmodernity as "fully developed modernity," with "institutionalized pluralism, variety, contingency and ambivalence," in which individual identity is guarded in an uncertain world. This stands in contrast to modernity, with its struggle for "universality, homogeneity, monotony and clarity" and failed mission to capture the world (Bauman $1992,187-188 ; 1998,57,66-69)$. Martin describes postmodernity in 
terms of a fluid "vision of culture, [where] all the walls and boundaries are collapsed," with the fragmentation of information resulting in free-floating signifiers (Martin 1998, 103; cf. Bauman 2000; Lyotard 1984, 40-41). In a sense, postmodernism differs from both traditionalism and modernism.

Modernism and postmodernism can be seen as rivals to religious traditionalism. I will use the term traditionalism to describe a tradition-based habitus in the HH. Traditional is a concept used by one wing of $\mathrm{HH}$ practitioners who draw on it in order to legitimize their practices as old and authentic, sometimes expressed in the labeling of practices as "biblical." Despite this, I find the concept useful to describe a habitus shared by those who oppose modernist and postmodernist tendencies. In addition, a rival habitus that manifests the tendencies described by Bauman is referred to by the term postmodern Pentecostal habitus. As illustrated by Raymond L.M. Lee, these two trajectories need not be mutually exclusive, but may coexist in the same group $(2005,75-76)$.

\section{The Finnish Pentecostal Movement Up to the 1970s}

The Finnish Pentecostal Movement dates back to a revival in the 1910s. Rather than a denomination, it can be described as a loose network of congregations. To some extent, Lutheran revival movements dating back to Pietism in the seventeenth and eighteenth centuries, as well as Baptism, Methodism, and Adventism in the nineteenth century, paved the way for Pentecostalism. All these movements favored the idea of exclusive communities of committed believers, free from state control and influence from the perceived secular world. This stood in sharp contrast to the traditional inclusive view of the Lutheran Church, where membership was obtained by infant baptism. Particularly important for creating precedence was the Laestadian movement, famous for its combination of strict moral teachings like abstinence from alcohol with ecstatic expressions such as speaking in tongues (Mantsinen 2014; Ruohomäki 2009). A further incentive for the revival was provided by expectations of a new era of Christian flourishing, interpreted as having been heralded by the preceding movements.

A group of middle-class Lutherans were the key figures who enabled the movement to catch on. In 1911, Hanna Castrén, founder and headmistress of a middle school (oppikoulu), Sörnäisten yhteiskoulu, and Pietari Brofeldt, former editor of Lutheran journal Kotimaa and soon-to-be Pentecostal journal "The Star of Hope" (Toivon tähti) teamed up with a few other middle-class Christians. They organized a Pentecostal revival 
tour together with the Norwegian Methodist-turned-Pentecostal preacher Thomas B. Barratt. The tour, and the groups sprouting from it, resulted in a nationwide network of communities with a common involvement in Pentecostal religiosity (Mantsinen 2014; Ruohomäki 2009, 2014).

Pentecostals were officially rejected by the Lutheran Church, especially when they advocated a Baptist view of baptism. The Pentecostals, in turn, rejected the Lutheran Church. The schism created a focal point of Pentecostal identity: the clear distinction between "the Church" on the one hand, and perceived "authentic Christianity," on the other, which they claimed to represent. However, in comparison with other Nordic countries, the Finnish Pentecostals had greater legal opportunities. In 1923, six years after Finland gained independence from Russia, a law of religious freedom was ratified. The law permitted the official registration of all religious movements, giving them legal status within the country, as well as the right for people to freely choose their religion. However, since the Pentecostals were critical of "church-like" organizations, the movement was not registered at the time (Ahonen 1994, 89-105, 169-173). Some Pentecostals went as far as to reject any kind of organization, including local congregations. These people-commonly called "Pentecostal Friends" (Helluntaiystävät)—did not become members of the newly founded Pentecostal congregations, although they could still participate in the same activities. The Pentecostal Friends remained a loose network until the 1980s, and traces of their tradition can still be detected in one or two places in Finland, like Pentecostal meetings in Multia (Ahonen 1994, 127-132; Mantsinen 2014).

In their first decades, $\mathrm{HH}$ groups attracted members mainly from the lower classes. Pentecostal culture and identity saw increased polarization internally as well, and featured a distinct class structure, although it was still shaped by earlier, mainly Lutheran revivals. Pentecostal culture was characterized by a popular and folkish preaching style; it was emotionally expressive and members upheld strict mental and social boundaries between them and the outside world. The first decades can be described as having been characterized by Weberian charismatic leadership. When the movement grew and traditions were shaped, the leadership moved in a patriarchal direction, with male elders leading the congregations (Mantsinen 2014).

Since its establishment, the $\mathrm{HH}$ has witnessed both internal conflicts and schisms. The most serious historical conflict, which resulted in a division of the HH, developed between 1960 and the early 1980s. In 1960, Vilho Soininen, one of the leading Charismatic figures in the movement-was 
ousted due to accusations of immoral conduct. As a consequence, he and his Siion congregation in Helsinki formed a new Pentecostal network: "The Free Pentecostal Movement of Finland" (Suomen vapaa Helluntaiherätys). This alternative Pentecostal network was able to unite a few congregations involved in local disputes and numbered a total of 3000 members at most. Over the next 20 years, however, many of them returned to the $\mathrm{HH}$, including the Siion congregation, and the new movement was dissolved. Although this was a dramatic incident, it only had temporary and local implications (Ahonen 1994, 316-317; Ristin Voitto 1985; Seila 1970), and with Soininen as one of the leading figures of the $\mathrm{HH}$, it is possible to imagine a scenario where the division would have been more permanent.

Post-World War II developments also posed challenges for the $\mathrm{HH}$ : Finland was increasingly bureaucratized, institutionalized, and had been transformed into a welfare state, where educational reforms enabled social upward mobility. The traditional affective sermon styles were no longer intellectually appealing to new generations of educated Finns. Moreover, the formerly widespread Lutheran-influenced understanding of Christian culture and morality has, since the 1960s, slowly been undermined by increased pluralization (Haastettu Kirkko 2012, 24-28). In the $\mathrm{HH}$, adoption of new practices, musical expressions, and forms of outreach also created tension within the movement. By the 1960s, acoustic guitar, accordion, and brass instruments, widely employed in outreach missions and services, had become an integral part of $\mathrm{HH}$ culture. The emergence of rock music and culture challenged the $\mathrm{HH}$ both from outside and from within. Some regarded them as "worldly" while others accepted and included them (Mantsinen 2014, 149-155).

A short-lived (1977-1981) Charismatic revival led by Pentecostal preacher Niilo Yli-Vainio was also important for introducing change into the $\mathrm{HH}$. This revival generated enthusiasm and visibility for Pentecostal religiosity. Even after the sudden death of Yli-Vainio, his legacy continued to inspire a range of religious practices. Additionally, new practices emerged, such as casting out demons of sickness. On the one hand, the new revival energized the $\mathrm{HH}$, while on the other it resulted in doctrinal disputes and local schisms. The casting out of demons in particular divided the Pentecostals. As new Charismatic leaders tried to imitate YliVainio, they were sometimes expelled from the $\mathrm{HH}$, and founded new, independent, congregations. The ministry of Yli-Vainio also strengthened the Lutheran Charismatic movement, extending Pentecostal practice outside the HH. Prior to the 1970s, relations between the Evangelical 
Lutheran Church of Finland and the Pentecostal Movement were mainly antagonistic. The Charismatic Movement within the church, as well as the ministry of Yli-Vainio, contributed to bring the Lutheran Church and the $\mathrm{HH}$ closer together and diminish tensions. In the 1980s, a dialogue was initiated, and the parties reached several agreements concerning basic rules and conduct. For example, the issue of burial ceremonies for people who were both members of the Lutheran Church and Pentecostal congregations was finally settled (Päätösasiakirja 1989).

At the same time, though, the improved relations undermined one of the cornerstones of Pentecostal identity: the dichotomy between the "dead religion" represented by the Lutheran Church, and the "true faith" represented by the Pentecostal Movement. Even though this way of thinking had already started fading, there was even less ground for nurturing division after the dialogue had commenced. Yet, not all were happy with these developments; some saw them as yielding the "true calling", and as a dangerous dalliance with liberal theologians and "ungodly priests." Nevertheless, for many it was a necessary step towards more balanced relations with other Finnish Christians (Ahonen 1994; Mantsinen 2016).

Looking outside the $\mathrm{HH}$, new Pentecostal groups have continued to form since the 1980s. Still, the Pentecostal Movement has remained strong, partly because its traditions had already been established, and partly because controversial phenomena, like casting out demons, were avoided. Today, Pentecostal groups outside the $\mathrm{HH}$ remain small; currently, the largest non-HH Pentecostal group has ca. 500 members, and the largest non-HH Pentecostal movement encompasses about 1300 members (Ahonen 1994, 341-364; Seurakuntien 2015).

\section{Diversification of the Pentecostal Movement: THE 1980s ONWARD}

Since the 1970s, the HH has continued to transform: The movement has become multigenerational and Pentecostal culture has changed and diversified. In the late 1980s, tent meetings with hymns, and rock concerts with popular bands like Heureka, presented two very different expressions of $\mathrm{HH}$ Pentecostalism. The movement had also grown substantially, making it difficult to manage its many missions and organizational bodies. Some of these developments brought questions of Pentecostal identity to the fore, leading to intense debate. 
Growth has resulted in calls for a united voice along with increased institutionalization, and support for an overarching denominational structure. The question has been a heated topic in the HH's most authoritative forum for discussion and cooperation: "Winter Days" (Talvipäivät)— currently "Autumn Days" (Syyspäivät), as at the forum is held at different times of the year. It resembles a synod, but is less rigid, and its authority is limited. At the Winter Days gathering in 1980, Valtter Luoto, the editor of Pentecostal journal Ristin Voitto, wrote an editorial about the importance of increased organizational cooperation. He deemed it remarkable that the $\mathrm{HH}$ as a loose network could work properly as a united movement, anticipating a need for an organization such as the Assemblies of God in the United States. At this point, the movement encompassed around 40,000 members, spread among 200 congregations. Its many projects and operations on national and international levels were impossible to realize without coordinated efforts. By then, the HH had established a publishing company, a missionary association, a Bible school, and multiple outreach organizations, including media (radio, and later also TV) ministries. These organizations demanded structure, leadership, and trained professionals. As the editorial illustrates, many Pentecostals wished for a national organization that would gather the movement around a common vision and give it a unified voice (Luoto 1980). The debate on organizational developments underlined the fact that the $\mathrm{HH}$ culture was not homogenous, contrary to what many thought.

Overall, the 1980s involved several turning points in the movement. New places to meet and assemble emerged in concert with new practices and evangelizing methods. For instance, worship music began to take root, with both domestic and international influences, exemplified by both the involvement of choirs at revival meetings (like in Yli-Vainio's ministry), and the use of translated, imported Anglo-American songs. The decade also witnessed a huge demographical shift. The number of converts declined, but the new generations of children - raised by Pentecostal parents — stabilized the number of baptized members at 45,000-50,000. Unlike their convert parents, the Pentecostal identity of the socialized members has been one of cultural continuity rather than disruption. They have never had to distance themselves from either "past life" or a "secular (Lutheran) church." In many cases, the previously strong stories of division between "the world" and the Pentecostal community have not necessarily coincided with the experiences of this new generation, leading them to question their social understanding of the boundary between sacred 
and secular. Perhaps unsurprisingly, it has been easier for them to accept and include expressions and practices from mainstream society, such as contemporary music and fashion. They also employ mainstream language rather than traditional "Pentecostal language" filled with biblical references and symbols. Moreover, they have a tendency to develop and appreciate theologies that focus on wellbeing in contemporary life rather than in the future and for eternity. The socialized members also differ from the older generations of Pentecostals in that they are mainly middle class. Although the class structure of Finnish society as a whole has moved in a middle-class direction, the shift in the $\mathrm{HH}$ is still significant. In contrast, of those few who converted during the 1980s and later, the majority come from lower strata in society (Mantsinen 2014, 2015b). As a consequence, the contemporary $\mathrm{HH}$ is comprised by two different categories of people: the older, converted Pentecostals of working-class origin, and the younger, socialized middle-class members. The diversification of the Pentecostal movement and its cultural modi have been vital to the emergence of the two different Pentecostal habituses, as described below.

Diversification of the $\mathrm{HH}$ has continued, and is visible in practices, services, media use, education systems, and leadership. Congregations have been founded in new types of locations, such as inside shopping malls. Some of them have been designed with specific groups in mind, such as Finnish youth or disadvantaged people. As the Internet expanded in the 1990s and the Finnish television channels were digitized in 2000s, the $\mathrm{HH}$ started employing these new media. Services and ministries have also been transformed, drawing on pop-cultural forms such as stand-up comedy, lifestyle sermons, and other entertaining types of service and outreach. At the same time, traditional Pentecostal practices and services have seen a drastic decline. For example, tent meetings are rare, traditional revival meetings scarce, and old forms of worship and prayer have been replaced by or coexist with new styles. For example, kneeling during services used to be commonplace, while now it is more common to stand up with lifted hands. Furthermore, traditional gender roles are questioned, and sometimes abandoned, which is visible in the gradual introduction of female pastors and elders (Mantsinen 2014).

The HH's education system has also changed in the last decades with the development of the Bible school. For a long time, it had relied on a curricular structure based upon one four-month course that could be taken by anyone, and, which also served as a basic training ground for preachers. The common understanding used to be that the Holy Spirit would inform and 
equip the preacher, and that reading the Bible was all that was required from the preacher himself. This ideal remained strong until the 1990s, when the level of education among younger members increased. As a result, social calls for higher quality preaching and ministry led to an overhaul of the education system. In the 1990s, the Bible school was transformed into a three-year, seminar-like institution, which offered a wide variety of courses and diplomas. Although formal education is still not required from a Pentecostal preacher in Finland, the pressure is mounting for this to change.

As for leadership, the charismatic authority type can still be found, although it no longer occupies the previous central position. In fact, all of the Weberian leadership and authority types are visible in the contemporary movement, but the emphasis has shifted over the years, somewhat as Weber described, through the routinization of charisma. The authority and popularity of charismatic leaders are still measured by their skills and ability to prove their uniqueness in the $\mathrm{HH}$. But within the congregations, they have to submit to local patriarchal authority, and to cultural Finnish norms and increased organizational structures.

Pluralization has changed the face of the $\mathrm{HH}$. It is no longer possible to speak of one common Pentecostal habitus. It makes more sense to speak of different habituses, where the focal points of Pentecostal identity differ between generations, and between converted and socialized members. Not all of these developments have met with approval; some have sparked controversies. New practices and styles of sermons have led to heated debates over their legitimacy. In the past decades, Pentecostals created new practices with evangelization and expansion in mind, and in order to tackle routinization, which was seen as an indication of stagnation and "dead religion." The emphasis on outreach made such introductions easier to legitimize in the Pentecostal logic. Since many of today's innovations are not directly focused on outreach, but have been created to meet the preferences of the members, they are harder to legitimize according to the old cultural system. In fact, some Pentecostals, particularly the older generations, fear that the incorporation of contemporary mainstream culture will destroy the movement from within, bringing in "the world" rather than leading to expansion.

\section{Contemporary Disputes}

At the turn of the millennium, all of the aforementioned changes and conflicts coalesced and culminated in one dispute that challenged the $\mathrm{HH}$ more than any other in the past decades had done. The dividing point was 
the registration of the Pentecostal Church of Finland (SHK) as a religious Finnish community. The decision was made on September 15, 2001, at a special meeting at which leaders or delegates from 131 of the HH's 230 congregations were present. The question, however, had older roots; the debate about and inquiry into registration had lasted for a decade. Not all congregations supported the registration and only 25 had made up their minds beforehand. Therefore, it was decided that those willing to form the registered church could do so. Others would not be forced to join. It was decided that the unity of the $\mathrm{HH}$ should be preserved and that the Winter Days would remain the collective forum for the whole of the $\mathrm{HH}$, regardless of the decisions in local congregations. Officially, the SHK was founded in January 2002. By September 10, 2014, 41 congregations and 8011 members had joined the church (Ketoja 2001; Kuosmanen 2001; SHK 2015; Sopanen 2002).

However, the registration processes were confusing and unsettling for many. They were already spurring debate at the Winter Days forum in 2002. Obscurities and differing views as to whether or not this type of organization was "biblical" led some to suggest a suspension of the process. However, a majority decided that 10 years of discussions and the previous year's decision had been enough. Comments from the opposing side were sometimes contradictory; one could advocate a common organizational structure, only to reject it if the word "church" was mentioned. Another concern that was expressed was that the SHK organization and its leaders would speak on behalf of the whole movement, without consulting all congregations (Kättö $2002 \mathrm{a}, \mathrm{b}$ ). Yet, up to that point, the largest congregation (Helsinki Saalem) and the publishing company's weekly (Ristin Voitto) editor had in fact already spoken on behalf of $\mathrm{HH}$ as a whole. Looking at the arguments, those who supported the SHK thought that the result would be a better organized movement, with one voice and an improved public image. Those who rejected the development saw the SHK as a fertile ground for the rise of religious dictatorship. In the most extreme cases, SHK was viewed as a dangerous ecumenical road leading to the apocalyptical church of the Harlot in the Book of Revelation. One female Pentecostal explained to me that she did not want to belong to "the Harlot Church," and therefore opposed the SHK (Fieldnotes 2014; Mantsinen 2016).

After the SHK was founded, some of the older Pentecostal leaders felt the need for another network for those who opposed the course the $\mathrm{HH}$ had taken. Their plans were further fueled by their experiences of exclusion and dismissal from the registration debate. In their opinion, opposition to 
the SHK did not gain enough attention either in the $\mathrm{HH}$, or in its journal Ristin Voitto (Helluntaikansa 2014; Mantsinen 2014). This experience of exclusion was the result of a number of other factors, foremost among which were educational and generational divisions. At the beginning of the millennium, younger and well-educated members had gained many positions of power, as pastors, organizational managers, and in Ristin Voitto. In cases where the journal seemingly favored the SHK, opponents interpreted editorial decisions to exclude their writings as pro-SHK action. From an outsider's perspective, however, editorial decisions seem to be based on common editorial standards of language, and perhaps a wish to avoid controversial topics and open condemnation. Differences in educational levels manifested themselves in differing abilities in terms of articulation and eloquence. In other words, differences in education and writing skills influenced the debate.

The opposition established "The Pentecostal People" association (Helluntaikansa, HK) on June 28, 2003. They started publishing their own journal, "People of the Cross" (Ristin Kansa, RK), in 2005. Later, a conference facility, Mertiöranta and three independent congregations, called "Traditional Pentecostal Churches" (Perinteinen helluntaiseurakunta, PHS), were founded. The creation of these PHS congregations had resulted from local disputes. Usually, such congregations were established in response to the founding of local SHK-congregations. Turning to the contents of the two journals, Ristin Kansa (RK) issues consist of devotional articles, traditional interpretations of the Bible, news from the missionary fields and from like-minded congregations, and biographies of previous Pentecostal leaders. Compared to Ristin Voitto $(R V)$, the editorial guidelines are more oriented towards evangelization. The language and biblical interpretations are more uniform than in the $R V$, which offers a wider scope of news, and invites some discussion on doctrinal issues and new interpretations of the Bible. Whereas the $R K$ depicts "the world" as hostile and "the end" as an imminent goal for the community of believers, $R V$ discourse is characterized by more individualistic goals and depicts "the end" in the relative long term.

The current schism has also resulted in alternative forums of practice, discourse, and power. The HH Bible school was founded in 1952, and has trained the majority of HH's preachers, missionaries, evangelists, and active members (Ahonen 1994, 302-307). Since the 1980s, the Bible school organization has also hosted the HH's major summer events. The remodeling of the Bible school as a new institution named Iso Kirja ("Big 
Book") in 1992 brought about strong reactions: some criticized, others applauded the shift towards more systematic teaching and thinking. The critique was intensified as some Pentecostals felt that the school was strongly pro-SHK. This contributed to the HK's decision to found another conference facility, named Mertiöranta (on the shore of Lake Mertiö), in 2012 (Helluntaiherätys 2014; Helluntaikansa 2014).

Iso Kirja and Mertiöranta can be seen as competitors, but may also be viewed as occupying different niches. They do not necessarily serve the same functions; their events, practices, and styles are obviously distinct, yet many Pentecostals visit both. Nevertheless, they are viewed as opposite bodies within the HH. Both train Pentecostals, and host conferences. Rather than competing by engaging in the same practices, however, they distinguish themselves rhetorically, educationally, musically, organizationally, and ideologically, as well as ritually (Havupalo 2014; Kuokkanen 2014). For example, Iso Kirja employs contemporary didactic and technological gadgets, like videos, whereas Mertiöranta lectures are more sermonlike and visual representation is minimal or absent. Their differences may be described in terms of postmodern (Iso Kirja) and traditional (Mertiöranta) habituses, manifested in their approaches to learning, thinking, and life in general. It is worth noting that the criticism of Iso Kirja is not limited to the $\mathrm{HK}$, but also voiced by traditional-oriented Pentecostals in general, who have expressed concern about changes, particularly in theological interpretations.

Another issue that divides the $\mathrm{HH}$ concerns leadership, not only how it should be defined and practiced, but also what titles should be used. For example, the naming of ministry workers divides opinions. The traditional titles "preacher" (saarnaaja) and "shepherd" (paimen) have lost some of their appeal. Many younger Pentecostals consider them old-fashioned and difficult to understand. Instead, "pastor" (pastori) and "leader" (jobtaja) have emerged as new titles. Many traditional Pentecostals find it difficult to accept the title "pastor", since it reminds them of the Lutheran title "priest," indicating institutionalization and loss of the "flame of the Spirit" (Helluntaikansa 2014). The divide within the $\mathrm{HH}$ also runs along the lines of leadership style and gender attitudes. On the HK side, leaders are regular preachers in the community, with concentrated authority according to traditional Pentecostal models. On the SHK side, the leadership is delegated to different individuals and specialists. In the $\mathrm{HH}$, traditional patriarchal leadership has included clear gender division, and the highest positions have been reserved for men. A pastor in one of the PHS congregations 
explained to me that they have "a traditional view" on leadership, meaning that only men are eligible to be congregational elders, preachers, and teachers. As mentioned briefly, some women have been elected as pastors in the twenty-first century, and a few have gained positions as elders. Usually, HK Pentecostals see this development as a sign of secularization of the movement, and as a step away from the rightful biblical tradition (Kuokkanen 2014; Fieldnotes 2014).

Among the loudest critics are a small number of older Pentecostal preachers, whose authority is based upon Weberian charisma and appeal amongst the older generations. Even though they have now officially retired, they have continued to play a crucial role in the creation of the HK and its particular brand of Pentecostal culture. These elderly leaders tend to interpret the trajectory of the $\mathrm{HH}$ in terms of decline. One of them described the current situation the following way: "What the fathers built, the sons dissolved (Lahti 2006)." In contrast, the younger generations do not necessarily understand what the fuss is all about, since they lack the experiences that formed Pentecostal identity among former generations. For them, the $\mathrm{HH}$ is in need of change in order to appeal to future generations both inside and outside the movement (Helluntaikansa 2014).

The conflict is not only played out in the Pentecostal press and larger organizational bodies, but on the local congregational level as well. In local conflicts, both sides fiercely defend their views, practices, and territory. In one such setting, the transformation of a traditional Pentecostal Association (the legal subject of the congregation) into a formal SHK congregation led to a lawsuit. The case concerned the ownership of the group's possessions, such as buildings and bank accounts. In the case "Järvinen v Pori Pentecostal Mission Registered Association" (Järvinen v Porin Helluntailähetys ry 2012), the civil court ruled the case in favor of the plaintiff, and the establishment of the SHK congregation was postponed. Local disputes concerning PHS congregations further contribute to the deepening of conflicts. Due to ongoing quarrels, PHS congregations are not currently recognized as a part of the $\mathrm{HH}$. This has led to situations where people who wish to switch from an SHK to a PHS congregation have not been granted the usual transfer documents, since the founding of the PHS was not mutually agreed. Mostly a symbolic gesture, this rejection still denies the PHS emotional ties to Pentecostal roots and identity. Ongoing disputes divide the movement further, as the older Pentecostal group can withhold $\mathrm{HH}$ status from newly established groups. 
The authority of the old forums is also being questioned, such as the Winter Days, and the SHK has not been able to gain recognition as the unifying voice of the Pentecostal Movement.

This is important, because it means that there is no organizational body or authority to unite the movement. Furthermore, the traditional schismatic public image of the $\mathrm{HH}$ has resulted in the founding of a couple of new and independent Pentecostal churches in the 2010s. The founders of these groups grew up in the $\mathrm{HH}$, but do not want to be associated with it (Fieldnotes 2014).

Within the HK, there is a fear that a church-like system of organization would bring about an authoritarian leader. This fear has its origins in past experiences in the $\mathrm{HH}$, as power struggles used to be common. Even though the SHK has limited the board member terms and distributed power throughout the organization, the fear has persisted (Havupalo 2014; Kuokkanen 2014; Seila 1970).

\section{Two Different Habituses}

Many Pentecostals view these divisions and disputes as the result of organizational developments aimed at obtaining juridical church status and different interpretations of that process. In my own research, I have found that the tensions within the movement have to do with larger sociocultural shifts in Finnish society and Pentecostal reactions to them, rather than doctrinal issues. The transformations so far discussed have produced two different Pentecostal habituses. For each, claims of a "true doctrine" primarily constitute a discursive strategy to legitimize one's own particular habitus as "biblical" and "truly Christian." With this strategy, Pentecostals also assert their opinion of the world outside the $\mathrm{HH}$, and its changing culture, as further illustrated below. In theoretical terms, they evaluate modern and postmodern influences and embrace or reject them, thereby drawing and redrawing boundaries between what, in scholarly terms, is often understood as the sacred and the profane.

An illustrative example comes from a retired couple in one of the PHS congregations. They explained to me that what they felt alienated them from the local Pentecostal congregation was its style of worship. They rejected not only the music, but also the entire culture that had developed around it, including the use of lighting effects and dress codes, all of which can be seen as pieces of the group's habitus. Therefore, they sought another group that better suited their preferences. As elucidated in this case, 
Pentecostal congregations and new PHS congregations do not necessarily compete for the same people, but fulfill the needs of people embodying different habituses. For many Pentecostals, these matters revolve around taste rather than doctrine. In this specific case, the couple brought up a doctrinal division only later, when the topic was broached. Doctrinal discourse is here a way to legitimize taste and habitus (Field Notes 2014).

Also pointing in this direction is a Sunday service in an older Pentecostal SHK church in the same locality as the PHS congregation I visited. The service included contemporary music with jazz influences. There was an orderly fashion to the structure and peoples' conduct, and the sermon was clear and systematic, dealing with people's daily problems. In contrast, the PHS service had a small choir that led the congregation through the traditional hymns. As the participants greeted one another, they employed old-fashioned Pentecostal words and phrases, and the small talk was filled with symbolic biblical language. In the same vein, the sermon consisted of a traditional, excited proclamation of the "Word," filled with emotion and exhortations (Fieldnotes 2014). During a discussion with the male elders of this PHS congregation, they briefly commented on secularization. For them, this was the main influence at work in the development of the $\mathrm{HH}$. For instance, they identified the new features described above, particularly the music, lighting effects, and new sermon content as signs of "worldliness." Complaints about "worldliness" may be seen as a response to disruption between traditional and familiar Pentecostal culture, and contemporary developments. In scholarly terms, this is an example of what was mentioned earlier: that for these men, the boundaries between the sacred and the profane had been breached. What further strengthens the importance of this example is that their responses are representative of wider segments of the contemporary HH (Fieldnotes 2014).

Although understandings of what constitutes "worldliness"- and the fear thereof-have been a common concern for Christians throughout history, such concerns have been accentuated in specific situations. In light of the current demographical and cultural changes on the one hand, as well as accusations of transgressions by preachers, and minimal or absent growth in the $\mathrm{HH}$, it is not surprising that such concerns have been aired by many Pentecostals, fueling concerns about worldliness. Also, Pentecostal adoption of practices from mainstream Finnish culture has doubtless undermined some of the traditional features central to historical Pentecostal culture. Since these developments have progressed rapidly, older generations in particular see them as threatening, and as undermining the perceived 
uniqueness of the HH. Perhaps unsurprisingly, concerns with worldliness are more widespread at the $\mathrm{HK}$ end of the $\mathrm{HH}$ spectrum than at the SHK end. People on the SHK side also voice their opinion on their opposition, but their critique revolves around other matters. From a researcher's perspective, each group's accusations of the other-of worldliness on the one hand, and of old-fashioned stagnation on the other-may be understood as a rejection of the preferences of the opposing camp. Using this rhetoric and line of reasoning, both sides define themselves and their relation to the other group, rather than describe that group; they create a distinction between good and bad taste. Sociologist Stephanie Lawler analyzes how people describe themselves by expressing disgust over styles and practices they do not appreciate, and do not want to be associated with. She uses the concept of disgusted subjects to refer to such identification processes (Lawler 2005). Similarly, Pentecostals" disgust over "worldliness" and "stagnation" respectively may be seen as ways of establishing their own habitus while distancing themselves from the alternative side (Mantsinen 2014; Fieldnotes 2014).

\section{Key Characteristics of the Habituses}

Presently, members leaning to either side represent two different forms of Pentecostal habitus, each formed by the members' background and generational experiences. In the following section, I describe a few key characteristics that demonstrate their different foci. The central standing of these features does not mean that the other side lacks such attributes; I merely want to illustrate the dominant directions in each of the camps.

Individual relationships to God are emphasized across the spectrum. However, on the SHK side these relationships are expected to develop in personalized ways, while on the HK side, they are expected to develop according to shared doctrine. For SHK members, individual relationships to God are open to discussion and new interpretations. Among HK members, this is less the case; established interpretations in general are rarely subject to serious discussion. The two sides also differ in terms of leadership structure. The SHK has a stronger inclination towards bureaucratic features, while the $\mathrm{HK}$ is mainly patriarchally led. Although charismatic authority exists in both camps, this feature is more predominant in the $\mathrm{HK}$.

Another divide can be seen in regard to rituals and service practices, mainly between intellectual and affectional forms. The more educated SHK Pentecostals prefer intellectual, well-structured rituals, and practices 
like sermons, and favor calmer emotional expressions. A rising trend among SHK Pentecostals is lifestyle sermons, familiar from international figures such as Joyce Meyer and Joel Osteen. HK sermons, by contrast, are typically more emotionally expressive; a standard HK sermon would utilize personal and folk stories, and would include references to biblical stories to greater extent (Mantsinen 2015a). The approach to religious experiences further divides the $\mathrm{HH}$. An important part of the traditional Pentecostal habitus was strong emotional experiences, which were not to be disputed. Today, the discourse of "freedom of the Spirit" has a stronger foothold in HK congregations than it has in the considerably more bureaucratic SHK organizations. A good example of the more orderly approach in the latter is the management of speaking in tongues, which has developed from a public expression into a private devotional routine (Mantsinen 2014, 124; cf. Cartledge 1998). In the SHK, Charismatic gifts and Charismatic preachers are usually subject to stricter control and critique than in the HK groups.

The employment of different discourses of legitimization also perpetuates division. I have found that HK Pentecostals are more prone to using biblical stories and interpretations in order to legitimize their arguments. This practice has declined radically amongst the new generations of socialized SHK members, whose debates are more intellectual and often lack direct biblical references. This ties into how each side has a distinct way of evangelizing. To SHK Pentecostals, reflective dialogue is key, whereas HK Pentecostals see proclamation as the appropriate way to go. Thus, SHK Pentecostals would engage in discussion with an outsider, while HK Pentecostals would proclaim the "correct" established message.

Attitudes to attendance and participation constitute another dividing line. Since the 1980s, attendance has declined dramatically in the $\mathrm{HH}$. The most important reasons for this are lack of interest in general and in high levels of social commitment, combined with increased acceptance of more "fluid", commitment-less, religious participation. Historically, participation has been the norm, and it still remains a strong sign of religiousness for the "traditional" HK wing (Mantsinen 2014). In contrast, new attitudes, widespread among younger generations, are more individualistic and do not demand steady church visits; one may instead practice at home.

If the habitus is conditioned by structural factors (Bourdieu 1990, 53-54), what has changed? It is obvious that Finnish society has changed dramatically since the 1950s, and that new generations of Pentecostals have been affected. The combined factors of the movement's internal 
developments and the increase in numbers of socialized members have produced a shift in habituses. Upward social mobility has created new circumstances, leading to different lifestyles and preferences. Class divisions are visible in both $\mathrm{HK}$ and SHK habituses. To say that the HK side would be completely in line with working-class culture would be misleading; some working-class features, such as social and political radicalism, are opposed by the vast majority of Finnish Pentecostals. Historically, Pentecostal culture in the $\mathrm{HH}$ has been more appealing to working-class taste, as is evident in its unrehearsed, folksy, immediate, and more direct expressions. While such elements still exist in SHK congregations, they have lost their appeal to middle-class Pentecostals, who prefer professional, carefully prepared, and intellectually stimulating elements. The $\mathrm{HK}$ side of the $\mathrm{HH}$ might consider these practices tending to favor expression at the expense of substance. The points of division between $\mathrm{HK}$ and SHK, as sketched here, run parallel to divisions of social strata, which means that social differences have placed their mark on Finnish Pentecostal habituses.

As demonstrated earlier, SHK and HK approaches to modern societal developments differ considerably. On the SHK side, we can see an attempt to offer responses to modernization by means of integrating popular culture. Conversely, the HK distances itself from these developments, offering an alternative. Generally, the traditionally popular features distinguish the HK side, whereas the SHK side is more elaborated and intellectualized. Moreover, postmodern emphases on loose boundaries, combined with openness to negotiating identities and participation, characterize a new Pentecostal habitus embodied by the SHK. The traditional Pentecostal habitus, embodied by the $\mathrm{HK}$, concentrates on community, established interpretations, and strict boundaries between "us" and "the world."

\section{A Struggle for the Future of Finnish Pentecostalism}

Change is inevitable in religious communities, since the members constantly interpret and reproduce the elements of their tradition (cf. Bloch 2001; Sperber 1996, 70-74). If development is slow, people usually have time to adjust to the changes taking place. Controversies are likely to arise with fast-paced major and visible changes that transform the structure and culture substantially. If the leaders of a Charismatic sect are still active when a structured organization is built, the shift may feel like a home invasion or an intrusion into their identity for them. 
The dynamics of Pentecostal religiosity pose a challenge for analysis. Donald E. Miller has used the concept postmodern primitivism to describe Pentecostalism. By this, he means that this mode of Christianity contains both primitive forms and postmodern tendencies. For example, it combines sometimes erratic experiences, discourses of self-improvement, speaking in tongues, and intellectually oriented sermons (Miller 1997, 22-24; Miller and Yamamori 2007, 142-44, 216-219). Historically, most Pentecostal movements have balanced on the edge between traditional and postmodern. This can explain some of the success of Pentecostalism in many countries. While offering something familiar and traditional, it also brings new and sometimes liberating ideas of individuality and social improvement. Such ideas include individual relationships with God and emancipation from poverty, as well as new forms of embodied practices and experiences (Robbins 2009, 62-63; Vasquez 2009).

The ambiguity and complexity inherent to Pentecostalism points to something important: The processes of division between traditional and postmodern within Finnish Pentecostalism have led to their separation and mutual opposition. The division of the $\mathrm{HH}$ into two opposite camps or habituses can be seen as a struggle between traditional and postmodern religion, whereby both sides have strong concerns about the future of Finnish Pentecostalism.

The ways in which these concerns are expressed very much resemble what O'Dea has listed as dilemmas of institutionalization. Especially relevant is the dilemma of delimitation: How should a religion be described and legitimized (O'Dea 1961)? Central to the dilemma are generational and socioeconomical differences between socialized and converted members. Generational conflicts are not new to the HH; as early as the 1960s, the different experiences of succeeding generations caused tensions in local congregations. The cultural boundaries between Pentecostals and the rest of society were guarded zealously at the time, and those who had called for faster progress usually resigned (Lindell 1991, 67-68). What distinguishes the present situation is that the movement has become relatively moderate towards society, and the number of converts has declined while the number of socialized members has increased; in other words, the situation has reversed. It is no longer common for "liberal" Pentecostals to leave the movement, never mind be expelled. Consequently, the $\mathrm{HH}$ has faced a dilemma of mixed motivation (O'Dea 1961), whereby the challenge has been to meet the needs of different groups. The ways in which these adjustments have been materialized has been problematic and a concern for those who support conserving the traditional Pentecostal habitus. 
This social development and differing experiences have led to both a new habitus and identity. Moderate conversion experiences, middle-class lifestyles, and postmodern tendencies have created a position where traditional Pentecostal culture is distant to many. When a new cultural position is introduced by a new habitus with new cultural practices, it challenges the social field and supporters of old positions. The traditional identity of exclusion and authenticity was a strong part of a shared habitus, and still is for the $\mathrm{HK}$ side of the $\mathrm{HH}$. As this position is threatened, traditional Pentecostals are feeling insecure and defend their identity and habitus (Bourdieu 1977, 80-81; 1983, 313; Mantsinen 2015b; Poloma and Green 2010,61-83). Younger generations and well-educated Pentecostals deem traditional practices and styles as outdated and ineffective in the current social and societal context. By rejecting and labeling the opposite side, they actively describe their own preferences and habituses. This distinction between "proper" and "outdated" is primarily a way to present one's own identity. The act of describing the other side actually portrays more of their own sphere than the opposite side. Presenting the other habitus as unwanted (cf. Lawler 2005) or "unbiblical" is a strategy of limiting the acceptable cultural sphere, deeming one's own preferences as legitimate. Other discourses are used as well: While the HK side seeks "authenticity" for the HH and Pentecostalism, the SHK side questions this version of "authenticity."

While speculating on the future of these trajectories, it is possible to present some preliminary prognoses concerning the different camps. The division may become irrelevant if the other side shrinks in popularity and size, as has happened before. It seems that the future of the HK will largely depend on how many new members, and foremost younger members, it will be able to attract in the future. The foremost threat against the future of the HK is the old age of the leading Charismatic figures. The authority of leading Charismatic figures has been a stabilizing force, and without new Charismatic leaders of this variety, the HK may face its demise.

Finally, the wider dispute between SHK and HK eclipses other challenges for the $\mathrm{HH}$, such as the disaffiliation of many socialized Pentecostal members, manifested in the creation of independent Pentecostal congregations. These new groups have resulted from their members' desire to differentiate their habitus from the established Pentecostal habituses within $\mathrm{HH}$. Usually founded by socialized Pentecostals, the new groups originated from the $\mathrm{HH}$. For them, the $\mathrm{HH}$ has not changed fast enough to accommodate their needs and visions - in analytical terms, it fails to 
accommodate the habitus they are seeking. The desired habitus includes a more individualistic and dynamic approach, open to contemporary fashion and music styles, as well as discussion of values and theologies.

\section{Conclusions}

The Finnish Pentecostal Movement has tried to foster an idea of a nationwide religious movement with a homogenous culture, and has failed. This is visible in the split that took place as SHK became a registered denomination and the HK network emerged as a response. In this chapter, I have argued that the split is the result of a larger differentiation within the $\mathrm{HH}$, embodied in two different Pentecostal habituses. The resulting main argument is that the Finnish Pentecostal Movement faces its greatest challenges from within, in terms of the said differentiation of traditional and postmodern Pentecostal habituses. These are the results of a wide variety of factors both internal and external to the movement. One of the key developments has been a demographical shift in the $\mathrm{HH}$, meaning that experiences vary between generations. The traditional Pentecostal habitus has been shaped by conversion, and strong distancing from mainstream society and the Lutheran state church in particular. The preferences inherent to this habitus also reflect the members' working-class background. With the relaxation of relations with mainstream Finnish society and Lutheran religion, the state church no serves as a threatening "other" to the same extent that it used to.

The emergence of a new, socialized, generation of Pentecostals has entailed a new habitus, lacking the old experiences of exclusion and separation; it constitutes a middle-class group of postmodern worshipers with more relaxed attitudes to mainstream society and practices. This group has grown to become influential in the $\mathrm{HH}$. Moreover, its preferences have influenced the whole movement: its members appreciate intellectual sermons that address individual needs, new embodied routines like worship music, organizational order, and decentralized authority. The construction of the new habitus has resulted in reactions from traditionalists. The latter camp sees innovations as "worldly," while the postmodern Pentecostals depict the traditionals as outdated and old-fashioned. Hence, the current organizational split can be viewed as a manifestation of this deeper divide.

It remains to be seen how the $\mathrm{HH}$ will develop in the future. Currently, Pentecostals from both camps find the contemporary culture of the $\mathrm{HH}$ 
alienating. There are plenty of socialized members who want to change the movement further, although the more traditional older generations have been the most vocal. One option is that the $\mathrm{HH}$ might allow two opposing groups to coexist in the same city or town, or even in the same congregation. It is also possible that the $\mathrm{HK}$ and other factions opposing the SHK might fail to attract long-term interest among younger Pentecostals, in which case the HK would slowly vanish. Yet another possibility would be to dissolve the $\mathrm{HH}$, but this seems unlikely in the near future, as it is not currently a viable option. In the long run, the movement's survival depends on the realization that groups with different religious habituses need their own spaces in which to practice Pentecostalism, and Pentecostal lifestyles that accommodate their own cultural tastes and preferences.

\section{REFERENCES}

Ahonen, Lauri K. 1994. Suomen helluntaiherätyksen historia. Vantaa: Ristin Voitto. Anderson, Allan H. 2014. An Introduction to Pentecostalism. 2nd ed. Cambridge: Cambridge University Press.

Barnett, Pual. 1973. The Quest for Power: Neo-Pentecostals and the New Testament. Sydney: Anzea Publishers.

Bauman, Zygmunt. 1992. Intimations of Postmodernity. London: Routledge.

- 1998. Postmodern Religion? In Religion, Modernity and Postmodernity, ed. Paul Heelas, 55-78. Oxford: Blackwell Publishers. 2000. Liquid Modernity. Cambridge: Polity.

Bourdieu, Pierre. 1977. Outline of a Theory of Practice. Cambridge: Cambridge University Press. [1972].

- 1983. The Field of Cultural Production, or: The Economic World Reversed. Poetics 12: 311-356.

- 1990. The Logics of Practice. Cambridge: Polity Press.

- 2000. Pascalian Meditations. Stanford: Stanford University Press.

- 2010. Distinction: A Social Critique of the Judgement of Taste. London: Routledge. [1979].

Bloch, Maurice. 2001. A Well-Disposed Social Anthropologist's Problems with Memes. In Darwinizing Culture: The Status of Memetics as a Science, ed. Robert Aunger, 189-203. Oxford: Oxford University Press.

Cartledge, Mark J. 1998. The Future of Glossolalia: Fundamentalist or Experientialist? Religion 28: 233-244.

Freston, Paul. 1999. Neo-Pentecostalism. In Archives des Sciences Sociales des Religions, ed. Brazil: Problems of Definition and the Struggle for Hegemony, vol. $105,145-162$. 
Helluntaiherätys. 2014. Finnish Pentecostal Movement. http://www.helluntaiheratys.fi. Accessed 25 June 2014.

Helluntaikansa. 2014. Pentecostal People Organization. http://www.helluntaikansa.fi. Accessed 25 June 2014.

Hollenweger, Walter. 1972. The Pentecostals. Minneapolis: Augsburg Publishing House.

Hunt, Steven J. 2002. Deprivation and Western Pentecostalism Revisited: NeoPentecostalism. Pentecostudies 1: 1-29.

Järvinen v. Porin Helluntaiherätys ry. 2012. Järvinen v Pori Pentecostal Mission Registered Association. Satakunnan käräjäoikeus L11/2531, verdict 12/17013 2012.

Kättö, Outi. M. 2002a. Rekisteröinti puhutti talvipäivillä. Ristin Voitto, Januari 23.

- 2002b. Rekisteröimättömyys aiheuttaa epävarmuutta. Ristin Voitto, January 30.

Ketoja, Kari. 2001. Päättämisen vaikeus ja oikeus. Ristin Voitto, September 26.

Kirkko, Haastettu. 2012. Suomen Evankelis-luterilainen kirkko vuosina 2008-2011. Tampere: Kirkon tutkimuskeskus.

Köhrsen, Jens. 2008. Religious Taste: Explaining Religious Choices by the Concept of Religious Taste. Paper Presented at the Annual Meeting of the SSSR, Louisville Kentucky, October 17, 2008.

Kuosmanen, Jorma. 2001. Valtakunnallinen neuvottelukokous päätti perustaa uskonnollisen yhdyskunnan. Ristin Voitto, September 26.

Lahti, Heikki. 2006. Pojasta tuli pappi: Heikki Lahti muistelee. Self-published.

Lawler, Stephanie. 2005. Disgusted Subjects: The Making of Middle-Class Identities. The Sociological Review 53: 429-446.

Lee, Raymond L.M. 2005. Bauman, Liquid Modernity and Dilemmas of Development. Thesis Eleven 83: 61-77.

Lindell, Liisa. 1991. Työpäen korttelista kaikkeen maailmaan: Tampereen helluntaiseurakunta 1921-1991. Tampere: Tampereen rukoushuoneyhdistys Saalem ry.

Löfstedt, Torsten. 2009. From Sect to Denomination: The Russian Church of Evangelical Christians. In Global Pentecostalism: Encounters with Other Religious Traditions, ed. David Westerlund, 157-178. London: I. B. Tauris.

Luoto, Valtter. 1980. Laajenevan herätysliikkeen ongelmat. Ristin Voitto, January 17.

Lyotard, Jean-François. 1984. The Postmodern Condition: A Report on Knowledge. Manchester: Manchester University Press. [1979].

Mahmood, Saba. 2005. Politics of Piety: The Islamic Revival and the Feminist Subject. Princeton: Princeton University Press.

Mamiya, Lawrence. 1982. From Black Muslim to Bilalian: The Evolution of a Movement. Journal for the Scientific Study of Religion 21: 138-152.

Mantsinen, Teemu T. 2014. Helluntailaiset luokkakuvassa. Uskontokulttuuri ja yksilön luokka-asema Turun belluntaiseurakunnassa. $\mathrm{PhD}$ dissertation, University of Turku, 2014. 
2015a. Postmoderni primitivismi: Helluntailaisuus ja uushenkisyys perinteisissä liikkeissä. In Näkyvä ja näkymätön uskonto, ed. Jaana Kouri, 128-140. Turku: University of Turku.

- 2015b. Conversion and Transformation of Culture in the Finnish Pentecostal Movement. Approaching Religion 5: 44-56.

- 2016. Suomen evankelis-luterilaisen kirkon ja helluntaiherätyksen muuttuneet suhteet työntekijöiden näkökulmasta. Teologinen Aikakauskirja, 120 (4): $337-351$.

Martin, Bernard. 1998. From Pre- to Postmodernity in Latin America: The Case of Pentecostalism. In Religion, Modernity and Postmodernity, ed. Paul Heelas, 102-146. Oxford: Blackwell Publishers.

Miller, Daniel E. 1997. Reinventing American Protestantism: Christianity in the New Millennium. Berkeley: University of California Press.

Miller, Daniel E., and Tetsunao Yamamori. 2007. Global Pentecostalism: The New Face of Christian Social Engagement. Berkeley: University of California Press.

Moberg, Jessica. 2013. Piety, Intimacy and Mobility: A Case Study of Charismatic Christianity in Present-Day Stockholm. PhD dissertation, Södertörn University.

Niebuhr, Richard H. 1957. The Social Sources of Denominationalism. New York: Meridian. [1929].

O'Dea, Thomas. 1961. Five Dilemmas in the Institutionalization of Religion. Journal for the Scientific Study of Religion 1: 30-39.

Päätösasiakirja. 1989. Päätösasiakirja: Suomen evankelisluterilaisen kirkon ja Suomen helluntaiherätyksen viralliset neuvottelut 1987-1989. Ristin Voitto ry.

Poloma, Margaret M., and John C. Green. 2010. Assemblies of God: Godly Love and the Revitalization of American Pentecostalism. New York: New York University Press.

Ristin Voitto. 1985. Helsingin Siion liitettiin helluntaiherätykseen. January 24.

Robbins, Joel. 2009. Pentecostal Networks and the Spirit of Globalization: On the Social Productivity of Ritual Forms. Social Analysis 53: 55-66.

Roos, J.P. 1988. Elämäntavasta elämäkertaan. Helsinki: Tutkijaliitto.

Ruohomäki, J. 2009. Karismaattisuuden kutsu: Karismaattisen kristillisyyden historiallinen kehitys helluntailiikkeeksi. Keuruu: Aikamedia.

Ruohomäki, Jouko. 2014. Suomen helluntailiikkeen synty, leviäminen ja ybteisönmuodostus 1907-1922. Keuruu: Aikamedia.

Seila, Taito. 1970. Mitä todella tapabtui. Helsinki: Ristin Sanoma ry.

Seurakuntien yhteys. 2015. Seurakuntien yhteys ry. http://seurakuntienyhteys.fi/ historia. Accessed 4 May 2015.

Sopanen, Tapio. 2002. Uskonnollinen yhdyskunta perustettiin. Ristin Voitto, January 23.

Sperber, Dan. 1996. Explaining Culture: A Naturalistic Approach. Oxford: Blackwell Publishers.

Stark, Rodney, and William Sims Bainbridge. 1985. The Future of Religion: Secularization, Revival, and Cult Formation. Berkeley: University of California Press. 
Streib, Heintz. 2011. Faith Development Theory Revisited: The Religious Styles Perspective. The International Journal for the Psychology of Religion 11: 143-158.

Suomen helluntaikirkko. 2015. Suomen Helluntaikirkon. http://www.suomenhelluntaikirkko.fi. Accessed 7 May 2015.

Vanberg, Viktor J. 1993. Rational Choice, Rule-Following and Institutions: An Evolutionary Perspective. In Rationality, Institutions, and Economic Methodology, ed. Christian Knudsen, Gustafsson Bo, and Uskali Mäki, 171-200. London: Routledge.

Vasquez, Manuel A. 2009. The Global Portability of Pneumatic Christianity: Comparing African and Latin American Pentecostalisms. African Studies 68: 273-286.

Weber, Max. 1947 [1925]. The Theory of Social and Economic Organization. London: Collier-Macmillan Limited.

- 1956 [1922]. The Sociology of Religion. Boston: Beacon Press.

1964 [1947]. The Theory of Social and Economic Organization. London: Collier-Macmillan.

\section{ETHNOGRAPHIC MATERIAL}

Field Notes from an Ethnographic Study of the Pirkanmaa Traditional Pentecostal Church in Tampere, Finland. February 23 February, 2014.

Interview with M. Kuokkanen from Pirkanmaa Traditional Pentecostal Church, February 23, 2014.

Interview with P. Havupalo from the Finnish Pentecostal Church, March 26, 2014.

Open Access This chapter is distributed under the terms of the Creative Commons Attribution 4.0 International License (http://creativecommons.org/licenses/ by $/ 4.0 /$ ), which permits use, duplication, adaptation, distribution and reproduction in any medium or format, as long as you give appropriate credit to the original author(s) and the source, provide a link to the Creative Commons license and indicate if changes were made.

The images or other third party material in this chapter are included in the chapter's Creative Commons license, unless indicated otherwise in a credit line to the material. If material is not included in the chapter's Creative Commons license and your intended use is not permitted by statutory regulation or exceeds the permitted use, you will need to obtain permission directly from the copyright holder.

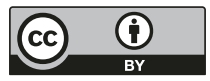

